Others had only a small effect-for example, in New York ${ }^{8}$ and Taiwan $^{9}$; we suspect that very few of these mothers were nutritionally at risk of having a poorly grown baby.

\section{IMPLICATIONS FOR INTERVENTION POLICY}

Clearly this and our other study' show that it would be inappropriate to give supplements to all Asian mothers. Selection is essential. An inadequate gain in triceps skinfold thickness during the second trimester seems a suitable method for identifying the nutritionally at-risk mothers. Since the increase in triceps skinfold thickness represents, in effect, a person's energy balance we suspect that this is a better indicator of nutritional risk than assessment of dietary intake, but we are studying this further. The method is certainly simple, cheap, and applicable to large numbers of patients, but unfortunately it will not be possible to apply this to mothers booking very late. Once the mother is selected at 28 weeks as being nutritionally at risk, should she be given a supplement-the logistics are daunting - or would dietary advice alone do ?

Ways of expanding these experimental observations into a routine service are being examined.

We are grateful to $\mathrm{Mr} \mathrm{H} \mathrm{N}$ Mansfield, consultant obstetrician, for allowing us to study patients under his care; Mr P Scott, head of the biochemistry department, Selly Oak Hospital; Mrs J King, research midwife; Miss K Snow, medical illustrations department, Birmingham Children's Hospital; the community midwives of areas 9 and 10; Mrs P Cox for secretarial help; and Beecham Research Laboratories, who provided the nutritional supplements.
Tables A, B, and C may be obtained from Dr B A Wharton.

\section{References}

1 Viegas OAC, Scott PH, Cole TJ, Mansfield HN, Wharton P, Wharton BA. Dietary protein energy supplementation of pregnant Asian mothers at Sorrento, Birmingham. I: Unselective during second and third trimesters. Br Med f 1982;285:589-92.

" Bissenden JG, Scott PH, King J, Hallum J, Mansfield HN, Wharton BA. Anthropometric and biochemical changes during pregnancy in Asian and European mothers having light for gestational age babies. $\mathrm{Br} \mathcal{F}$ Obstet Gynaecol $1981 ; 88: 999-1008$.

${ }^{3}$ Department of Health and Social Security. Recommended daily amounts of food energy and nutrients for groups of people in the United Kingdom. Reports on health and social subjects. No 15. London: HMSO, 1979.

${ }^{4}$ Thomson AM, Billewicz WZ, Hytten FE. The assessment of fetal growth. fournal of Obstetrics and Gynaecology of the British Commonwealth 1968;75:903-16.

${ }^{5}$ Gore S. Assessing clinical trials-trial discipline. Br Med $\mathcal{F} 1981$;283: 211-3.

${ }^{6}$ Lechtig A, Habicht JP, Delgado H, Klein RE, Yarbrough C, Martorell R. Effect of food supplementation during pregnancy on birthweight. Pediatrics 1975;56:508-19.

7 Mora JO, de Paredes B, Wagner M, et al. Nutritional supplementation and the outcome of pregnancy. I. Birth weight. Am F Clin Nutr 1979; $32: 455-62$.

${ }^{8}$ Rush D, Stein Z, Susser M. A randomized controlled trial of prenatal nutritional supplementation in New York City. Pediatrics 1980;65: 685-97.

9 Blackwell RO, Chow BF, Chinn KSK, Blackwell B, Hsu SC. Prospective maternal nutrition study in Taiwan: rationale, study design, feasibility and preliminary findings. Nutrition Reports International 1973;7: 517-32.

(Accepted 4 fune 1982)

\title{
Influence of previous gold toxicity on subsequent development of penicillamine toxicity
}

\author{
P J SMITH, W R SWINBURN, D R SWINSON, I M STEWART
}

\begin{abstract}
The incidence of penicillamine toxicity was determined in 250 patients who had never previously received gold, 76 patients who had received gold without toxic reaction, and 79 patients with a previous history of gold toxicity. The results suggest that there may be a higher incidence of penicillamine toxicity in patients who have previously shown toxic reactions. The interval between stopping the gold and starting the penicillamine did not influence incidence of toxicity. The development of a rash during gold treatment does not seem to influence the development of a rash during penicillamine treatment, but patients who have had proteinuria or bone-marrow depression during gold treatment may have an increased likelihood of developing a similar side effect with penicillamine.
\end{abstract}

Wrightington Hospital, Appley Bridge, Nr Wigan, Lancs WN6 9EP P J SMITH, MRCP, consultant rheumatologist W R SWINBURN, MRCP, consultant rheumatologist

D R SWINSON, MRCP, consultant rheumatologist

I M STEWART, MRCP, consultant rheumatologist

\section{Introduction}

There have been conflicting reports on the effect of previous gold treatment on the subsequent development of penicillamine toxicity. The multicentre trial group found no increased toxicity in patients who had previously received gold treatment. ${ }^{1}$ Webley and Coomes also reported no overall increase in the incidence of side effects, but rashes and possibly bone-marrow depression were commoner in patients who had previously received gold. ${ }^{2}$ Dodd $e t$ al found an increased penicillamine toxicity in patients who had previously had adverse reactions to gold and also an increased risk if the penicillamine was given within six months of stopping the gold. ${ }^{3}$ Steven et al concluded that there was no increased incidence of toxic reaction to second-line drugs in patients who had previously been treated with gold or penicillamine and that the interval between the drugs had no influence on the outcome. ${ }^{4}$

\section{Patients, methods, and results}

The records of 405 patients with rheumatoid arthritis who had been given penicillamine were studied. A total of 250 had never received gold, 76 had received gold without adverse effects, and 79 had a history of gold toxicity. In all cases of toxicity the side effects were considered sufficiently severe to stop the drug; mild or transient side effects have not been included. Patients with upper gastrointestinal 
side effects with penicillamine were also excluded as these were unlikely to be related to previous gold treatment; these numbers were small and if included do not alter the conclusions. Of those patients with bone-marrow depression, one had neutropenia on gold and subsequently had proteinuria with penicillamine, and one had neutropenia with penicillamine. All others had thrombocytopenia.

Penicillamine toxicity was recorded in 46 of the $250(18 \%)$ who had never received gold, 15 of the $76(20 \%)$ with no history of gold toxicity, and 27 of the $79(34 \%)$ with previous gold toxicity. Although there appears to be an increased incidence of penicillamine toxicity in patients who had had gold toxicity compared to those who had not, this is not statistically significant ( $\chi^{2}$ with Yates's modification $=3.39$; $p=0.07$ ). Comparison of penicillamine toxicity in those who had never had gold with all those who had showed a marginally significant increase in toxicity with previous gold treatment $\left(x^{2}=3.76 ; p=0.05\right)$. If those who had never had gold were compared first with those with no previous gold toxicity $\left(\chi^{2}=0.88 ; p=>0 \cdot 10\right)$ and then with those who had had gold toxicity $\left(\chi^{2}=7 \cdot 77 ; \mathrm{p}=<0.01\right)$, the difference is significant only with the latter group, suggesting that the difference between the two groups who have previously received gold did not reach statistical significance because the numbers were not sufficiently large.

The interval between treatments was studied in 75 patients who had had gold toxicity. In 31 cases penicillamine had been given within six months of stopping gold, and in more than half of these the interval was less than one month: six of these 31 patients (19\%) developed toxic reaction to penicillamine. In the remaining 44 cases the interval was more than six months, in over half it was more than two years: 18 of these 44 patients $(40 \%)$ developed penicillamine toxicity. Although there appears to be an increased risk of developing penicillamine toxicity with a longer interval, the difference is not statistically significant. Twelve patients had similar side effects on gold and penicillamine: in only three of these was the penicillamine given within six months of stopping gold. In these 12 patients the mean interval between treatments was $\mathbf{4 1}$ months compared with 30 months in the patients who had different adverse effects.

We found no increased risk of developing a rash with penicillamine in patients who had developed a rash with gold (table). Of 10 patients

Incidence of side effects to penicillamine in patients with and without previous reactions to gold

\begin{tabular}{|c|c|c|c|c|}
\hline & \multirow{2}{*}{$\begin{array}{c}\text { No } \\
\text { studied } \\
(n=405)\end{array}$} & \multicolumn{3}{|c|}{$\begin{array}{l}\text { Incidence of side effects to } \\
\text { penicillamine }\end{array}$} \\
\hline & & $\underset{(n=41)}{\text { Rash }}$ & $\begin{array}{l}\text { Proteinuria } \\
(\mathbf{n}=20)\end{array}$ & $\begin{array}{c}\text { Bone- } \\
\text { marrow } \\
\text { depression } \\
(\mathrm{n}=20)\end{array}$ \\
\hline $\begin{array}{l}\text { No previous gold treatment } \\
\text { No previous reaction to gold } \\
\text { Previous reaction to gold: } \\
\text { Rash }(n=61) \\
\text { Proteinuria }(n=10) \\
\text { Bone-marrow depression }(n=4)\end{array}$ & $\begin{array}{r}250 \\
76 \\
79\end{array}$ & $\begin{array}{l}23(9) \\
10(13) \\
8(10) \\
7\left(11^{*}\right) \\
=\end{array}$ & $\begin{array}{l}12(5) \\
2(3) \\
6(8) \\
4\left(40^{*}\right)\end{array}$ & $\begin{array}{l}10(4) \\
2(3) \\
8(10) \\
= \\
2\left(50^{*}\right)\end{array}$ \\
\hline
\end{tabular}

* Percentage of number with previous specific reaction.

who had had proteinuria with gold, however, four also developed proteinuria on penicillamine. Of four patients who had had bonemarrow depression with gold, two had a similar side effect with penicillamine. These numbers are small, but using Fisher's exact test these reach a significance of $p=0.0008$ for proteinuria and $p=0.013$ for bone-marrow depression.

\section{Discussion}

Gold and penicillamine are effective in suppressing disease activity in about the same proportion of patients with rheumatoid arthritis. ${ }^{5}$ Previous treatment with gold does not seem to influence the likelihood of responding to penicillamine. ${ }^{12}$ In agreement with Dodd et al, ${ }^{3}$ our findings suggest that there may be an increased incidence of penicillamine toxicity in patients who have previously had toxic reactions to gold. Dodd suggested a wait of six months after stopping gold for toxicity before starting penicillamine. For a patient who needs suppressive treatment, six months of pain, stiffness, and systemic disturbance is a long time. Dodd's and other reports on this subject are based on small numbers of patients. We felt that this was an important point to resolve and collected a relatively large number of cases. Differences will remain in different series due to selection and criteria for stopping the drugs. We found no evidence that the interval between drugs has any influence on the development of toxicity.

Dodd found that all 15 patients in whom penicillamine was given within six months of gold being stopped because of toxic reactions developed side effects, and 13 of these developed similar side effects on the two drugs. He suggested that the penicillamine might be mobilising the gold from the tissues by virtue of its chelating properties. We would disagree with this conclusion as in our patients only three out of 31 patients developed similar side effects on the two drugs when the interval was less than six months. The mean interval between treatments in our patients was somewhat longer for those who developed similar adverse reactions. We feel that a more likely explanation is that certain patients are more likely to react adversely to either drug. Bone-marrow depression and proteinuria seemed particularly liable to occur in certain patients with both drugs. This is supported by Panayi, who showed that there was an increased incidence of tissue types HLA-B8 and DRW3 in patients who developed proteinuria with either gold or penicillamine. ${ }^{6}$

We thank Mr A C C Gibbs, University of Manchester, for help with statistical analyses and Mrs M Hunt, Royal Infirmary, Blackburn, for secretarial help.

\section{References}

1 Multicentre trial group. Absence of toxic or therapeutic interaction between penicillamine and previously administered gold in a trial of penicillamine in rheumatoid disease. Postgrad Med $\mathcal{f} 1974 ; 50$,suppl 2: 77-8.

2 Webley M, Coomes EN. Is penicillamine therapy in rheumatoid arthritis influenced by previous treatment with gold ? Br Med F 1978;ii:91.

${ }^{3}$ Dodd MJ, Griffiths ID, Thompson M. Adverse reactions to D-penicillamine after gold toxicity. $\mathrm{Br} M e d \mathcal{f} 1980 ; 280: 1498-500$.

4 Steven MM, Hunter JA, Murdock RM, Capell HA. Does the order of second-line treatment in rheumatoid arthritis matter? Br Med $\mathcal{F} 1982$; 284:79-81.

5 Huskisson EC, Gibson TJ, Balme HW, et al. Trial comparing Dpenicillamine and gold in rheumatoid arthritis. Ann Rheum Dis 1974; 33:532-5.

6 Panayi GS. Genetic predisposition to gold and penicillamine induced drug toxicity [Abstract]. Scand $\mathcal{f}$ Rheumatol 1980;33,suppl:15.

(Accepted 14 fuly 1982)

ONE HUNDRED YEARS AGO The brother (non-medical) of one of our members resident in Honolulu, gives the following description of the modus operandi of the Hawaiian midwife. "The midwives here are for the most part men-usually old men. When the woman's time draws near and labour commences, she is placed sitting on a man's knee with her back to him. He then clinches his hands over her abdomen, and with all his strength hugs the woman to him, until the child is actually forced into the world, falling to the floor between the operator's feet. The umbilical cord is then cut, and always left very long. Then the woman is placed upon her feet, and the midwife takes her tongue, and draws it steadily until she gulps, or retches, this action causing the prompt ejectment of the after-birth. After this she goes and flounders about in the sea, and returns to land, ready for such domestic duties as may fall to her lot or inclination. Native children are-as may be inferred from the way in which they are introduced to existence-very easily born; but should the baby stick at all, or make any bother about being born, then the mother knows it is going to be half white, as this latter kind of baby is so much bigger in the forehead. It is a wise child that knows its own father in this country. So well recognised is this fact that natives never ask, 'Who is your father ?' but only, 'Who is your mother ?' when they desire any acquaintance with one another's genealogy." (British Medical fournal, 1882.) 